\title{
Metabolism and Inactivation of Progesterone
}

\author{
Hirohiko TAKE \\ Department of Obstetrics and Gynecology, Kyoto Prefectural University of Medicine, Kyoto, Japan
}

(Director professor : Gen-ichi Tokuda, M.D.)

Recently, many synthetic progestine were reported to be useful for clinical purposes. And many of these durgs are effective in both oral and subcutaneous administration. Progesterone, which is natural progestin, however, is inactive when administered orally. The inactivation of orally administered progesterone has been supposed to be due to the ring A reduction of progesterone in the liver. But the metabolism of orally administered progesterone has not yet been well analyzed.

In this experiment, metabolism of peogestserone was studied in three groups of Clauberg rabbits.

1. 3H-Progesterone was administered subcutaneously.

2. 3H-Progesterone was administered orally.

3. 3H-Progesterone subcutaneously and 14C-progesterone orally were administered.

After extraction of free steroid with chloroform (free fraction), the urine was hydorlyzed with $\beta$-glucuronidase and extracted with chloroform (glucuronide fraction). The urine was further hydrolyzed with $\mathrm{HCl}$ on the boiling water bath and extracted with chloroform (sulfate fraction). These chloroform extracts were washed with $\mathrm{NaOH}$ and water, and evaporated. The extracts were combined and the combined extract was adsorbed on alumina with benzene and eluted stepwise with different concentrations of methanol in benzene. Each $10 \mathrm{ml}$ effluent was collected and the radioactivity was counted.

In this experiment the following results were obtained.

1. No marked difference in the distribution of excreted radioactivities in each of free, glucuronide and sulfate fraction batween Group 1 and 2 was observed.

2. In Group 3, similar 3H/14C ratio was observed in each of free, glucuronide and sulfate fraction.

3. Column chromatography revealed three radioactive peaks. The elution pattern of radioactivities from the column in Group 1 was similar to that in Group 2.

4. In Group 3, no marked difference in the $3 \mathrm{H} / 14 \mathrm{C}$ ratio of the three radioactive peaks was observed.

5. One of the urinary metabolite was identified as 20 $\alpha$-hydroxypregn-4-ene-3-one by paper chromatography, acetylation, deacetylation, chromic acid oxidation and recrystalization.

6. 20 $\alpha$-hydroxypregn-4-ene-3-one was excreted in urine as glucuronide and the radioactivities were counted as $3-4 \%$ of the administered doses.

7. In Group 3, urinary excretion of $14 \mathrm{C}$ was faster than that of $3 \mathrm{H}$. 
8. Experiment with blood, after administration of radioactive progeaterone, revealed that the ratio of radioactivities incorporated into free fraction to the conjugated fraction was 23 times greater in Group 1 than in Group 2.

These results indicate that, in the Clauberg rabbit, the glucuronidation of C-20 reduced matabolite of progesterone, in addition to the ring A reduction, plays a significant role in the inactivation of progesterone in vivo.

(pp. 494 504) 


\title{
Progesterone の代謝と不活性化に関する研究
}

\author{
京都府立医科大学産婦人科学教室（主任 徳田源市教授） \\ 武博 \\ 彦
}

（昭和41年10月29日受付）

\section{第 1 章 緒言}

Rozenkranz $\left.{ }^{1}\right)(1950)$ にり黄体ホルモンの合成が完成されて以来，各種の合成 progestin が次々に作られ 臨床面で広く応用されるようになつた。特に近年経口避妊という新しい分野の研究において，あらためてて れら steroid の経口的効果とう面に強い関心がもたれ研究されているが，ぞんな psogestin でも経口投与で 有効とはいえず．経口投与によりほとんど効果があらわれないものもある。一方これら各種 steroidの progestational activity を測定するためには，従来より子宮粘膜の反応性を指標とする Corner \& Allen 法”), Clauberg 法3), McPhail 法 ${ }^{4}$, Hooker Foebes 法5)等があり,また Lutwakmann ${ }^{6}$ (1955) は子宮粘膜中に Carbonic Anhydrase が存在するととを確認したが，その activity を測定する方法が検討され，てれの測定にPhilpor \& Philpot 法7)や Miyake \& Pincus 法 $\left.^{8}{ }^{9}\right)^{9}$ 用用いられている。

内因性 progestin である progesterone の代謝については, Marrian ${ }^{10}$ ) (1929)が妊婦尿より pregnane- $3 \alpha$, 20 $\alpha$-diol を分離して以来, progesterone は体内で $\Delta^{4}$-3-ketone と G-20-ketone の還元を受け尿中に排墈さ れると考えられ, progesterone の代謝還元物としての pregnanediol が尿より抽出されるととは多くの報告 がある. Engel ${ }^{11)}$ (1941)は progesterone を家鬼の皮下および閒脈静脈に注射して，その生物学的活性を Clauberg 反応で観察した結果, 後者の場合が弱く, また脾内に注射しても同様に弱いととを報告しており, てのような実験から progesterone か肝ておいて不活性化されるととはかなり古くからわかつていた。にし て progesterone の 20-ketone 還元体は明らかな progestational effect をもつているので，てのような経 口投与時の progesterone が肝で不活性化されるのは, A-ring の 2 重結合の還元か源因であると考えられて いる12). しかしててで A-ring の還元のみが progesterone の不活性化にあずかつているのかどうかを progesterone の生体内での代謝の問題とともにあらためて考光てみることは今後の各種合成 progestin の研 究の上に有意義であると考えられる，幸いにも近年 isotope 標識化合物の導入により種々の steroid の生体 内代謝に関する研究が進んで来たので，著者も radioactive progesterone を家鬼没投与し，経皮経口両投与 方法時の progesterone 代謝の相異を検討したとてろ，興味ある結果が得られたので，その成績を報告する とともに，若干の考察をところみた。

\section{第 2 章 全編を通じての実験方法}

\section{I . 採尿方法}

a. 持続導尿による方法

雌家鬼の尿道は臸入口より深く, 腟の前壁に開口しており, 導尿に際し, 腟入口よりネラトンカテーテル （No. 4) を插入しても，尿道内に挿入するてとはむずかしい，とかく子宮頸管を経て子宮内に入り勝ちにな る. そこで恥骨の際で開腹し, 膀胱をあらわし, 指を膀胱後壁に沿つて入れ, 㓐入口より插入したカテーテル の先を誘導しながら尿道を経て膀胱内に導くようにした，插入後カテーテルが自然抜去することを防ぐため に䏽入口に組系をもつて結さつ固定し，あわせて尿が漏れないようにした，持続導尿された家鬼は，Fig. 1 のように特製のカゴに入れて自由に動けないように板で閂み, カテーテルを通つて出て来る尿を一定時間で とに採取し，尿は直ちにろ過して氷結保存した。 
Fig. 1. Method of urine collection by indwelling catheter

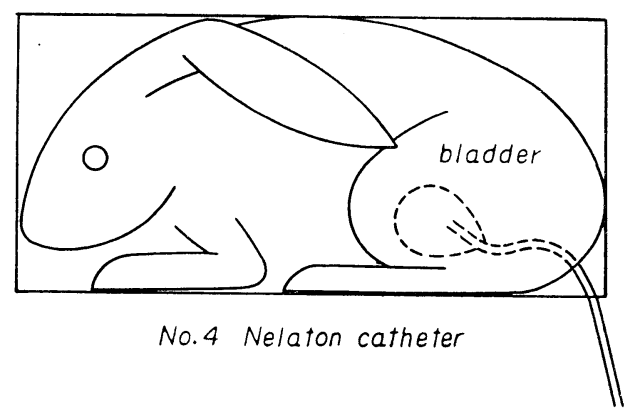

\section{b. metabolic cage を用いる方法}

Fig. 2 に示すような特製の cage を作製して，糞と尿とが混ざら ないようにして採尿した，採尿時間は 24 時間を単位に 5 日間採取し t.

\section{II. 採血方法}

頸動脈よりできるだけ全血を採取し，採取後速やかに2500r.p.m. 20分問遠心器にかけて血清を分離して氷結保存した.

\section{III. 水解および抽出方法}

尿中 steroid は遊離型の他, glucuronide, sulfate 等の結合型で
Fig. 2. Method of urine collection by metabolic cage

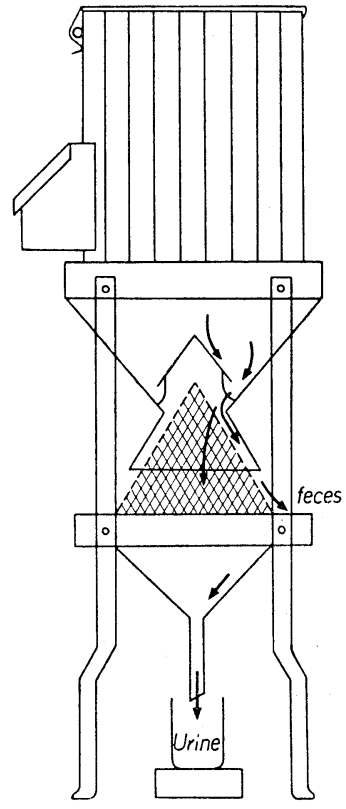

存在し，遊離型はそのままで抽出測定できるが，結合型は水解によつて遊離型として抽出測定しなければな らない. progesteroneの metabolite の水解は普通酸水解が行なわれるが, 酸水解の場合には, glucuronide も sulfate も同時に水解されるので選択的にてれを抽出することはできない， $\beta$-glucuronidase を用いた酔 素水解を行なえば最初 glucuronide だけを水解することができる.

Pregnanediol の抽出に際して，一般に用いられる抽出溶媒は Toluene であるが，Toluene では極性の強 い steroid が抽出されにくく，すべての metabolite を抽出するために chloroform を抽出溶媒として用い t.

先ず尿または血清をpH4.5に醋酸で調整し，これに pH 4.5の Acetate Buffer を1/10 量加え，倍量の chloroform で 3 回抽出した。 なお emulsion ができた場合は遠心分離し, chloroform 首を合わせて free fraction とした. 残つた水層に $\beta$-glucnronidase $(600 \mathrm{unit} / \mathrm{ml})$ を加え, penicillin 2 万単位を混入し $37^{\circ} \mathrm{C}$ 24時間 incubate した.

これを倍量の chloroform で3 回抽出分離し, chloroform 層を合わせて glucuronide fraction とした. 水層にさらに conc, $\mathrm{HCl} 15 \% \mathrm{v} / \mathrm{v}$ 加えて, $100^{\circ} \mathrm{C} 30$ 分間温浴上で加熱し, 急冷後倍量の chloroform で 3 回 抽出分離し, chloroform 層を合わせて sulfate fraction とした, なお各抽出 chloroform 層は $1 / 10$ 量の $\mathrm{N} / 10 \mathrm{NaOH}$ で 2 回, 蒸溜水で 3 回洗涤後, 芒硝により脱水し, 蒸発乾固した.

\section{Column chromatography}

Steroid の column chromatography の吸着剤には Silica-Gel, Florisil, Alumina およびイオン交換樹 脂等が用いられている。 Alumina は corticoid のような steroid を一部分解すると言われているが，progesterone metabolite の場合はこのような分解がおこらず, 分離能が非常にすぐれているので, 本実験では Alumina を用いた。 すなわち, Brockmann Alumina (standardiziert) $6 \mathrm{~g}$ をクロマト管 (内径 $1 \mathrm{~cm}$ に立 填し, benzene で steroid を吸着したのち, 溶出溶媒として Benzene, 0.1\% methanol-benzene (M-B) $0.3 \%$ M-B, 0.5\% M-B, 1\% M-B, 5\% M-B, 30\% M-B, methanol 各 100ml を用いて steroid を溶出した. 溶出 
液は fraction collector を用いて10mlずつを分画採取した。

\section{V. radioactivity $の$ 測定}

Radioactivity の測定には Packard Tri-Carb Model 314A の liquid scintillation spectrometer を使

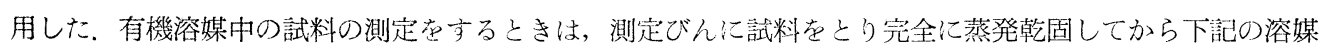
$\mathrm{A}$ を $10 \mathrm{ml}$ 加光，よく溶解してから測定した。B Blank は溶媒 $\mathrm{A} 10 \mathrm{ml}$ を測定びんにとり使用した。また水性試 料を測定するときは，その0.5mlを測定びんにとり下記溶媒 $\mathrm{B}$ を $10 \mathrm{ml}$ 加党，よく混ぜてから測定した。この 場合 Blank は測定びんに蒸留水 $0.5 \mathrm{ml}$ とり溶媒 $\mathrm{B}$ の $10 \mathrm{ml}$ と共使用した。 なお steroidの精製の進んでい ない段階では，色素による quenching がおこるため補正を必要とした。これには一定 count 数(測定試料 の count 数と同程度の count 数のあるもの) の ${ }^{3} \mathrm{H}$ あるいは ${ }^{14} \mathrm{C}$ をその試料および Blank 亿添加して測定 し補正した。

溶媒 A

$$
\left\{\begin{array}{lc}
\text { Toluene } & 1,000 \mathrm{ml} \\
\text { P.P.O. } & 4 \mathrm{~g} \\
\text { P.O.P.O.P. } & 0.1 \mathrm{~g}
\end{array}\right.
$$

溶媒 $\mathrm{B}$

$\left.\begin{array}{lr}\text { Toluene } & 330 \mathrm{ml} \\ \text { Dioxan } & 330 \mathrm{ml} \\ \text { Ethylcellesolve } & 330 \mathrm{ml}\end{array}\right\}+\left\{\begin{array}{lr}\text { P.P.O. } & 4 \mathrm{~g} \\ \text { P.O.P.O.P } & 0.1 \mathrm{~g} \\ \text { Naphthalen } & 75 \mathrm{~g}\end{array}\right.$

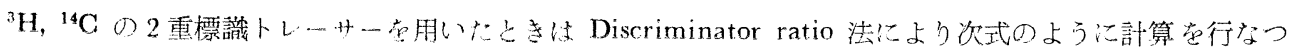
$た^{13}$,

${ }^{3} \mathrm{H},{ }^{14} \mathrm{C}$ の標準試料の window 1 , window 2, 亿甫け当 discriminator ratio $\frac{\mathrm{C}_{2}}{\mathrm{C}_{1}}=\mathrm{b} \cdots$ (1), $\frac{\mathrm{H}_{2}}{\mathrm{H}_{1}}=\mathrm{a} \cdots$ (2)

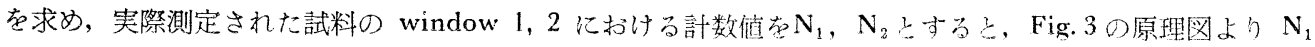
$=\mathrm{H}_{1}+\mathrm{G}_{1} \cdots$ (3) $\mathrm{N}_{2}=\mathrm{H}_{2}+\mathrm{C}_{3} \cdots$ (4)々なり, (1)(2)(3)(4)の式より

$$
\mathrm{H}_{1}=\frac{\mathrm{bN}_{1}-\mathrm{N}_{2}}{\mathrm{~b}-\mathrm{a}}, \quad \mathrm{C}_{3}=\frac{\mathrm{b}\left(\mathrm{N}_{2}-\mathrm{aN} \mathrm{N}_{1}\right)}{\mathrm{b}-\mathrm{a}}
$$

なる式ができる。

$\mathrm{H}_{1}, \quad \mathrm{H}_{2}$ は window 1.2 亿おける ${ }^{3} \mathrm{H}$ の計数値でむり, $\mathrm{C}_{1}, \mathrm{C}_{2}$ は window 1,2 こおける ${ }^{14} \mathrm{C}$ の計数値である。本測定の之

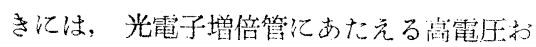
よび 2 組の window をいずれの window

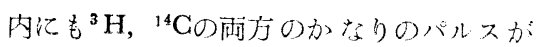
法いるように説定する必要がある。

VI, 20a-hydroxypregn-4-en-3-one の合成

Progesteaone 加方 20 $\alpha$-hydroxypregn-4en-3.one t合成するのは, ほば Thomos ${ }^{14}$ ) の方法によつた、をなわち $1 \mathrm{ml}$ の methanol Fig. 3. Discriminator ratio method

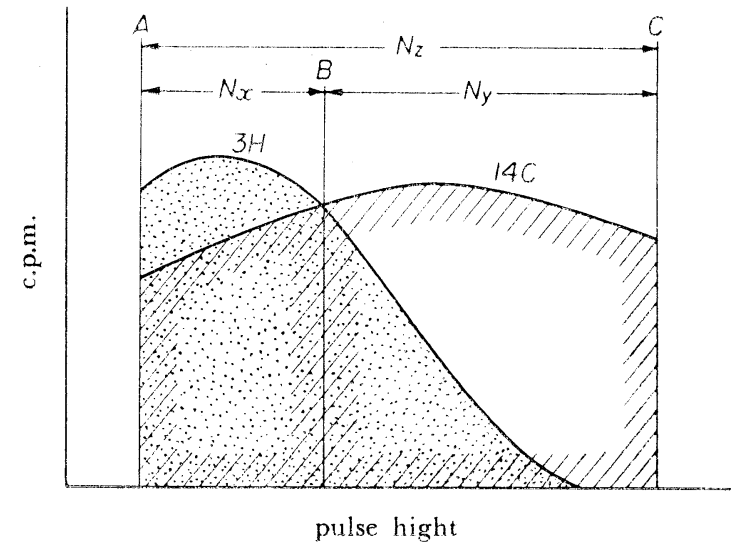
に progesterone $(100 \mathrm{mg})$ 在溶解し，てれに pyrrolidine $(0.1 \mathrm{ml})$ t加克て， $\mathrm{N}_{2}$-gas 下で $100^{\circ} \mathrm{C}$ 温浴上で 2 分 間加熱後急冷すると， crystal (3-N-pyrrolidine enamine) ができる。これを ice-cold Methanol で数回洗 涹してから蒸発乾固し，Ether $(15 \mathrm{ml})$ に溶汃して lithium aluminum hydride $(60 \mathrm{mg})$ を加えて1時間 よく混合する。混合が終了してからて机に注意深く Acetate buffer $(1.6 \mathrm{ml}$ の醋酸と1.6 $\mathrm{g}$ の醋酸ナトリウム を $22 \mathrm{ml} の 10 \%$ aq. methanol に溶解したもの) を加光，Ether を分離蒸発後，残つた methanolic solution

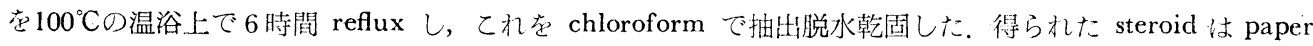


chromatography (Benzene : Ligroin : Methanol : water =70:130:160:40) を用い下行法で展開すると,

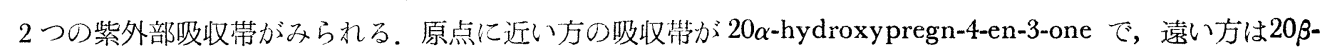
epimer である. paperより各吸収带を methanol で溶出し, rechromatography をして精製した.

\section{第 3 章 経皮投与 progesterone の代謝}

春験方法：生物学的活性をしらバる時と同様の方法で家兔に progesterone 老投与した。すなわち proges terone が充分働く状態にするため，まず estrogen priming をおてなつた。体重 $1 \mathrm{~kg} の$ 䧳家鬼に (estradiol $5 \mu \mathrm{g}$ を 6 日間皮下注射し，その翌日 ${ }^{3} \mathrm{H}$-progesterone $(4 \mu \mathrm{c}$ in $1 \mathrm{ml}$ sesame oil $)$ を大腿部皮下に注射し, 前述 bの方法で24時間尿を 5 日間採取した。なお使用した注射器および試料びんは methanol で充分洗い残つた count 数を测定し, 投与量の補正を行なつた。採取した尿は前述亚の方法で加水分解し抽出した後, Alumina Golumn chromatography で分画した。また測定は前述Vの liquid scintillation spectrometer で行なつた。 実験成績：この尿中 metaboliteの elution pattern 在図で示すとFig. 4のようになり，それぞれ著明な

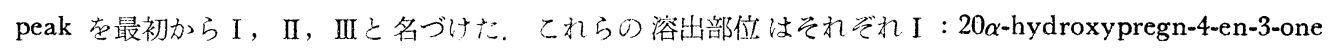
II : pregnane- $3 \alpha, 20 \alpha$-diol, III : pregnane-3 $\alpha-6 \alpha-20 \alpha$-triol に一致した.

これらのうち 20a-hydroxypregn-4-en-3-one の定性試験結果をまとめてみるとFig. 5 およびTable 2 のよ

Fig. 4. Elution pattern of progesterone metabolites from alumina column (Subcutaneous administration)

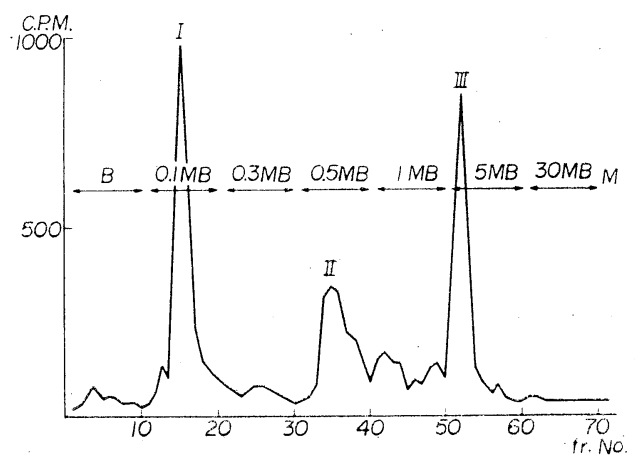

Table 1. The percent distribution of radioactivity in the urine after subcutaneous adminiation of radioactive progesterone

\begin{tabular}{l|r|c|c|c}
\hline \hline $\begin{array}{l}\text { Experiment No. } \\
\text { Fraction }\end{array}$ & 1 & 2 & 3 & 4 \\
\hline $\begin{array}{l}\text { Free and } \\
\text { glucuronide }\end{array}$ & 36 & 50 & 41 & 7 \\
\hline $\begin{array}{l}\text { Sulfate } \\
\text { Acidic }\end{array}$ & 7 & 16 & 10 & 18 \\
\hline \begin{tabular}{l} 
Uneatractable \\
\hline
\end{tabular} & 37 & 15 & 32 & 30 \\
\hline
\end{tabular}

Fig. 5. Identification of $20 \alpha$-hydroxypregn4-en-3-one on paper chromatogram

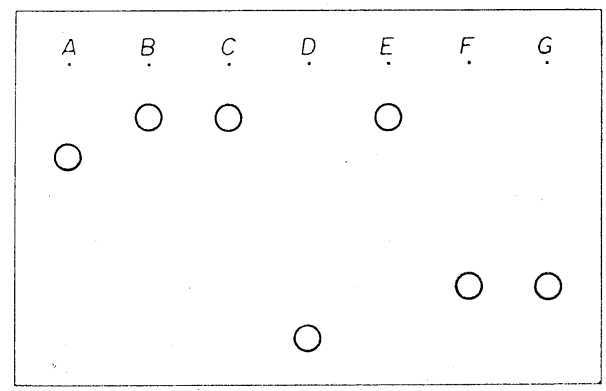

A : 20ß-hydroxypregn-4-en-3-one standard.

B : 20 $\alpha$-hydroxypregn-4-en-3-one standard.

C : metabolite (elution patternI) in rabbit urine

$\mathrm{D}$ : acetylated C

$\mathrm{E}$ : deacetylated D

$\mathrm{F}$ : oxydized $\mathrm{E}$

$\mathrm{G}$ : progesterone standard.

Table 2. UV absorption spectra \& sulfalic acid chromogen spectra of progesterone \& its metabolite

\begin{tabular}{|c|c|c|}
\hline & \multicolumn{2}{|c|}{ Maximum absorption } \\
\hline & $\mathrm{MeOH}$ & $\mathrm{H}_{2} \mathrm{SO}_{4}$ \\
\hline B & $240 \mathrm{~m} \mu$ & $290 \mathrm{~m} \mu$ \\
\hline $\mathrm{C}$ & 240 & 290 \\
\hline $\mathrm{F}$ & 240 & 291 \\
\hline $\mathrm{G}$ & 240 & 291 \\
\hline
\end{tabular}


うになる。すすなわち peak 1 は acetic anhydride pyridine で容易に acetyl 化され, deacetyl 化するて とにより元の steroid にもどるが, 他方クロム酸で酸化するととにより paper chromatogram 上 progesterone 亿一致する spot が得られ，乙の steroid の紫外線吸収 spectrum, sulfulic acid chromogen spectrum などはどれも progesterone に一致した。他方 spot は $\mathrm{MeOH}$ 中で $\Delta^{4}-3$-ketone 構造に特有な $240 \mathrm{~m} \mu$ に一 致する吸収 peak を示しており，したがつてクロム酸で酸化された $\mathrm{OH}$ 基は $\mathrm{C}_{20} \mathrm{OH}$ であるととになる。す なわち peak I は20 $\alpha$-hydroxypregn-4-en-3-one であるてとが明らかになつた。

尿中に排泄された metabolite の free, glucuronide, sulfate, acidic 等の各 fraction における radioactivity をみると Table 1 亿示すように本実験の抽出過程では投与量の 25 40\%が acidic および unextractable fraction 江移行し， steroid の回収量を減少させているが，40\%近くは free および glucuronide fraction に得られ，15\%近くが sulfate fraction に得られた。 また尿中に排泄された $20 \alpha$-hydroxypregn-4-en-3-one は計算上投与量の $2.6 \sim 3.7 \%$ あつつた。

\section{第 4 章 経口投与 progesterone の代謝}

实験方法：経皮投与の時と同様 estorogen priming t在行なつた Clauberg 家鬼に ${ }^{3} \mathrm{H}$-progesterone $(4 \mu \mathrm{c}$ in $1 \mathrm{ml}$ sesame oil) を経口投与した。すすなわち臨床上未熟罗の保育に使用する鼻腔栄養用カテーテル管を家 鬼の口腔より胃内に插入して投与した。 なお投与後使用した注射器, ビニール管および試料びんに残つた試 料は methanol で充分洗い，一括して count 数を測定し投与量の補正を行なつた。採取した尿は経皮投与 の場合と同様の方法により加水分解，抽出，Alumina Column Chromatography の操作を行なつた，測定 も同様 liquid scintillation spectrometer を用いた。

実験成績：尿中 metabolite の elution pattern 在図で示すとFig. 6 のようになり，ての尿中 metabolite の free, glucuronide, sulfate, acidic 等の各 fraction の radioactivity の分布をみるとTable 3 のうに, ぞれも経皮投与の成績とあまり変化はみられなかつた。 また尿中に排泄された $20 \alpha$-hydroxypregn-4-en-3one は前章と同様に同定され投与量に対して3.3〜3.7\%が排泄され経皮投与のそれとあまり変らなかつた. Hoffman $^{15)}$ (1942) は家鬼に Fischer ${ }^{16}$ )（1953）は人に progesterone を経皮および経口投与したとき，尿中 pregnanediol への代謝に量的な差異は認めなかつたと言つている。 しかしこてで家鬼の場合 $20 \alpha$-hydroxy pregn-4-en-3-one が尿中に排出されるから従来より言われているように，経口投与によつて不活性化すなわ ち A-ring の還元が増加するのであれば，乙の 20-ol 体の尿中への排泄が経口投与では著明に減少していな ければならないはずである。しかし本実験ではての 20-ol 体の尿中排泄量にも経口経皮両投与方法で差は認 められなかつた。しかし同一家鬼を用いた実験ではないのでその判定は必ずしも容易ではない，そてで次に 同一家鬼を用いて経口経皮両投与方法を行なつた。

Fig. 6. Elution pattern of progesterone metabolite from alumina column (Oral administration

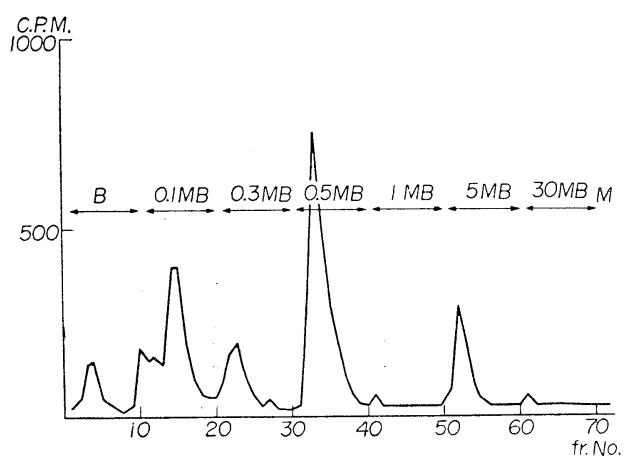

Table 3. The percent distribution of radioactivity in the urine after oral administration of radioactive progesterone

\begin{tabular}{|c|c|c|c|c|}
\hline $\begin{array}{l}\text { Experiment } \mathrm{No} \\
\text { Fraction }\end{array}$ & 1 & 2 & 3 & 4 \\
\hline $\begin{array}{l}\text { Free and } \\
\text { glucuronide }\end{array}$ & 59 & 47 & 65 & $\begin{array}{c}5 \\
56 \\
\end{array}$ \\
\hline Sulfate & 14 & 13 & 8 & 14 \\
\hline Acidic & 16 & 25 & 21 & 21 \\
\hline Unextractable & 11 & 15 & 6 & 4 \\
\hline
\end{tabular}




\section{第 5 章 経口経皮同時投与 progesterone の代謝}

実験方法 : estrogen priming をした Clauberg 家鬼に ${ }^{3} \mathrm{H}$-progesterone ( $1 \mu \mathrm{c}$ in $1 \mathrm{ml}$ sesame oil) を経 皮投与し，同時に ${ }^{14} \mathrm{C}$-progesterone ( $1 \mu \mathrm{c}$ in $1 \mathrm{ml}$ sesame oil) を経口投与して前述 a の方法で持続導尿に より 2 〜 時間ごとに48〜 72時間採层し加水分解, 抽出測定の方法は前章と同様に行なつた.

実験成績：尿中 metabolite の elution pattern および尿中 metabolite の free, glucuronide, sulfate, および acidic の各 fraction における radioactivity の分布をそれぞれ Fig. 7, Table 1, 3 の No. 4 に示し た。同一家鬼に経皮経口同時投与を行なつても metabolite の elution pattern や各 fraction の radioactivity の分布は，単独投与例とほぼ同様の成績が得られた。 また尿中に排泄された $20 \alpha$-hydroxypregn-4en-3-one を前章と同様に同定し，その尿中排泄率をみると投与量の $3.3 \%$ が経皮投与で，4.8\%が経口投与で 得られた。 このように metabolite の pattern は同様であつても, metabolite の排泄速度が両投与方法に どのような相異があるかをみるために，前述の実験と同様経皮経口同時投与で 1 時間でとに得た尿の radioactivity を測定しててれを図に示すとFig. 8 のようなり，経口投与の場合は投与後速やかにその radioactivity は上昇し，投与後 $3 \sim 4$ 時間で perk となり，その後急速に減少の傾向がみられたが，一方 経皮投与の場合その peak は経口投与にくらべてやや遅れ，4〜6時間後となり，その上昇および減少の curve は経口投与に比較してかなり沟るやかであつた。すすなお経口投与ではその尿中への排泄が経皮投与 に比較して速いと言える。言い換えると尿中排泄の態度は血漿中の radioactivity の濃度を主として反映す るものであるから，その血中濃度の状態が両投与方法において相異しているはずであるから，次の実験でて れを検討した。

Fig. 7. Elution pattern of progesterone metabolite from alumina column (Simultaneous administration)

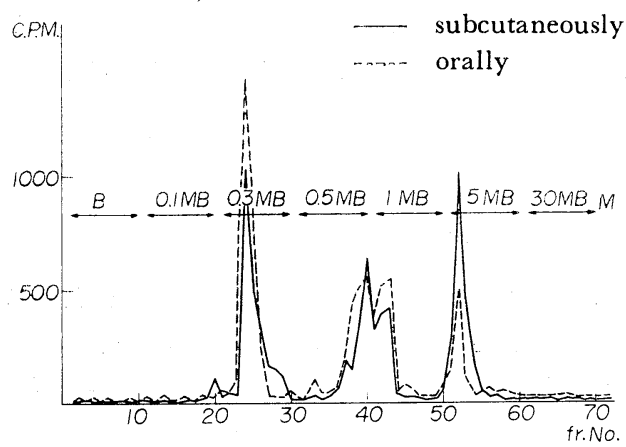

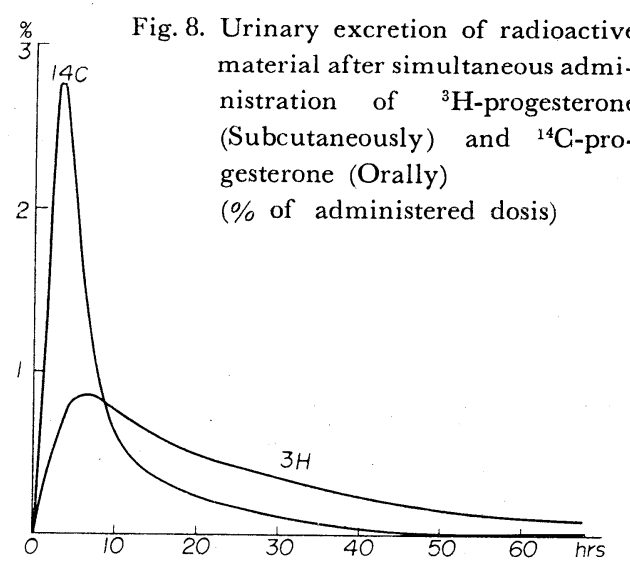

第 6 章 progesterone の経ロおよび経皮投与時の血中 radioactivity

実験方法: estrogen priming をした Clauberg 家鬼に ${ }^{14} \mathrm{C}$-progesterone $(2.5 \mu \mathrm{c}$ in $1 \mathrm{ml}$ sesame oil) 在経皮および経口投与して，投与後 4 時間 目に頸動脈および心より穿刺により速やかに全 血を採取し, 血清を分離して加水分解抽出後, その血中 metabolite の radioactivity 在測定 した.

実験成績 : Progesterone 投与後の血中の free, glucuronide, および sulfate 各 fraction の radioactivity の分布をみるとTable 4 亿示すよ
Table 4. Plasma radioactivity after administration of ${ }^{14} \mathrm{C}$-progesterone subcutaneously or orally

\begin{tabular}{lc|c|cc}
\hline & $\begin{array}{l}\text { Subcutaneous } \\
\text { administration }\end{array}$ & $\begin{array}{c}\text { Oral } \\
\text { administration }\end{array}$ \\
\hline Free (f) & 1570 & G.P.M. & 425 & G.P.M \\
\hline Glucuronide (g) & 1489 & 9600 & \\
\hline Sulfate $\quad(s)$ & 2435 & 24000 \\
\hline$\frac{\mathrm{f}}{\mathrm{f}+\mathrm{g}+\mathrm{s}} \times 100$ & $29 \%$ & $1.3 \%$ \\
\hline
\end{tabular}


らに，経皮投与の場合血中 free steroid の占める radioactivity は，経口轧与の場合の約23倍の制合であつ た.このととは経口投与された progesterone は腸より吸収さ礼門脈を経て肝で inactivate されるために systemic circulation にはいる free steroid が少なくなり，一方 conjugate metabolite が高値となつて現わ れるものと考觉られる。

\section{第 7 章＼cjkstart静注および経口分割投与 progesterone の代謝}

実験方法：estrogen priming tした Claubesg 家鬼にプロルトン静注用(Schering 社製) のprogesterone $1 \mathrm{mg}$ を連続 5 日間耳静脈より静注して total $5 \mathrm{mg}$ 投与後, 翌日開腹して子宮を取り出した。 その生物学的 活性の判定には後述の McPhoil 法4)および Carbonic anhydrase activity (GAA) の判定 $\left.\left.{ }^{7}\right)^{8}\right)^{9}$ 亿よつた。

また progesterone $1 \mathrm{mg}$ 存 estrogen priming tした Clauberg 家兔に 6 時 間でとに連続 3 日間経口投与して, 同 様子宮粘膜に対する生物学的效果をみ た.

実験成績 : 静注投与例ではは経口投 与例と同様にその生物学的効果は認め られなかつた。乙れは一面，静注投与 は経口投与と同様に排泄が速やかなた

Table 5. Bioassay of progesterone

\begin{tabular}{|c|c|c|c|c|c|}
\hline \multicolumn{4}{|c|}{ Method of administration } & \multirow{2}{*}{$\begin{array}{l}\text { C.A.A } \\
(\mathrm{Eu} / \mathrm{g})\end{array}$} & \multirow{2}{*}{ McPhail } \\
\hline & $\begin{array}{c}\text { Daily } \\
\text { dose }\end{array}$ & $\begin{array}{c}\text { Duration } \\
\text { days }\end{array}$ & $\begin{array}{c}\text { Total } \\
\text { dose mg }\end{array}$ & & \\
\hline Oral & $1 \mathrm{mg} \times 4$ & 3 & 12.0 & 60 & + \\
\hline Subcut & $\frac{1}{3} \mathrm{mg} \times 1$ & 3 & 1.0 & 100 & H \\
\hline Oral & $10 \mathrm{mg} \times 1$ & 5 & 50.0 & 70 & + \\
\hline
\end{tabular}
め target organ に達して，それに作用するだけの hormone level を維持できないのではないかと考光ら れるので，次に分割経口投与在行なつて，ある程度の血中濃度が経皮投与の場合と同様保持するてとができ， 平等な hormone level が保てるようにててろみたが，Table 5 にその成績をみるように，その生物学的効果 は対照として行なつた経皮投与 1 日1/3mg・3日間連続投与例にはるかに预よばなかつた。このこよより両 投与方法に上る排泄速度の相異と生物学的効果との間に，なんら相互関係は認められなかつたことになる。

\section{第 8 章 progesterone および related compound の生物学的活性}

\section{实験方法：}

Carbonic anhydrase activity (CAA)

体重 700 1,200 g の幼若家鬼に estrogen priming として estradiol を1 日 1 回連続 6 日間大腿皮下に 注射, 続いて各種 steroid 1 日 1 回連続 5 日間経皮または経口投与した。投与終了の翌日頸動脈切断放血 後, 開腹して子宮を摘出した，次に子宮角より約 $1 \mathrm{~cm} の$ 部分を幅約 $5 \mathrm{~mm}$ に輪切し，10\% Formalin 液に 固定して，後述の McPhail assay に供した。残りの子宮は小剪刀で縦に切開した後，冷生食水で軽く 3 回 洗い，ろ紙上に切開した子宮をのせて過剩の水分を吸収させ，小鋭匙をもつて粘膜を搔爬して，得られた粘 膜を torsion balance で計量し, 重量の10倍量の蒸留水と共に氷浴中で potter の homogenizer で磨研し

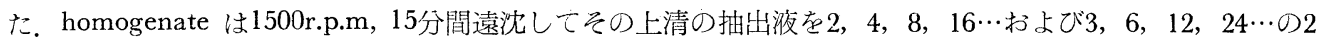
系列の倍数稀䣋液として測定は Philpot \& Philpot ${ }^{7}$ の変法平清水 $\left.{ }^{17}\right)$ の方法で行なつた.

McPhail $^{4}$ ) Assoy

前述の切除した子宮片を10\% Formalin で固定し,バラフィン包埋 $5 \mu$ の切片として, hematoxylin-eosin

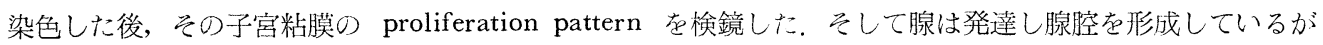
粘膜表層に限られ, 深部の間質におよんでいないもものを(十), さらに腺の数と深さが増し, 腺の增殖は主 として対子宮間膜側にあるものを(+十), 腺增殖は一様に粘膜に拡がり, 腺は深さを增して閒質の深部にまで 侵入し，間質の減少がみられるものを(卅)，腺增殖が高度で間質を貫妨筋層近くにまで侵入し，粘膜襞 がわずかに保存され，粘膜は破れてみえるものを(册)と表現した。

6-dehydro-progesterone 0 合成 
ほほ Agnelle \& Laubach $^{18}$ )の方法に従つて行な つた。すなわち progesterone $(1.0 \mathrm{~g})$ 亿第 3 Butanol $70 \mathrm{ml}$ おび chloranil $1.7 \mathrm{~g}$ を加え, $\mathrm{N}_{2}$ gas 中 5 時間 $100^{\circ} \mathrm{C}$ 温浴上で reflux し, 急泠後 $300 \mathrm{ml}$ の蒸留水を加え methylene chloride $30 \mathrm{ml}$ で 3 回抽出し, 抽出液に petroleum ether $150 \mathrm{ml}$ を加えて2\% sodium hydrosulphite $15 \mathrm{ml}$ て3 回, $1 \mathrm{~N}-\mathrm{NaOH} 20 \mathrm{ml} 5$ 回, 丞留水 $20 \mathrm{ml} 55$ 回 洗滌後, 芒硝で脱水し蒸発乾固した。 乙れを alumina $22 \mathrm{~g}$, 内径 $1.9 \mathrm{~cm}$ のクロマ管でalumina column chromatography を行なつた. 溶出方法 は, 抽出物を hexane-benzene $(1: 1)$ で吸着した のち, 同液 $100 \mathrm{ml}$ を, ついで benzene $300 \mathrm{ml}$, $0.1 \%$ methanol-benzene $100 \mathrm{ml}$, 最後にmethanol $50 \mathrm{ml}$ で浴出した。 なお溶出液は $10 \mathrm{ml} 1$ fraction として fraction collector 在用いて分画採取し た. 各溶出液を蒸発させ, methanol を用いて結 晶させると benzene 溶出開始後 4 本目から 24 本 目までの試験管底に結晶の析出が認められた。こ れを一括して集め methanol で再結晶を数回行 なうと，白色の結晶物が得られた。乙の結晶の methanol 中での紫外線吸収 spectrum みる と, Fig. 9 のよに $285 \mathrm{~m} \mu$ で peak 走す 6dehydroprogesterone が得られた。

実験成績 : 実験に用いた steroid は progesterone および 6-dehydroprogesterone であり，それぞれ経 皮経口投与した時の progestational activity を C.A.A. および McPhail assayで行なつた成績を示すと Table 6のようになり，経口投与例 では progesterone に生物学的活性 が涩められないように 6-dehydroprogesterone も同様に生物学的活 性を認めることができなかつた。

6-dehydroprogesterone は $\Delta^{4.6} の$ double bond 持つており, progesterone のように A-ring の還元が 起こり難いのに経口投与で不活性を 示しているのは, 他に別の route で 不活性化されるものと考光られる。

\begin{tabular}{|c|c|c|c|c|}
\hline & \multicolumn{2}{|c|}{$\begin{array}{c}\text { Method of } \\
\text { administration }\end{array}$} & \multirow{2}{*}{$\begin{array}{c}\text { C.A.A. } \\
\text { (average Eu/g) }\end{array}$} & \multirow{2}{*}{ McPhail } \\
\hline & & Dose (mg) & & \\
\hline \multirow{6}{*}{ Progesterone } & \multirow{2}{*}{$\mathrm{S} \cdot \mathrm{C}$} & 1 & 100 & H \\
\hline & & 2 & 120 & 册 \\
\hline & \multirow{4}{*}{$\mathrm{P} . \mathrm{O}$} & 4 & 30 & - \\
\hline & & 8 & 40 & - \\
\hline & & 10 & 50 & + \\
\hline & & 50 & 50 & + \\
\hline \multirow{4}{*}{$\begin{array}{l}\text { 6-dehydro- } \\
\text { progesterone }\end{array}$} & S.G & 2 & 120 & $H+H$ \\
\hline & \multirow{3}{*}{$\mathrm{P} . \mathrm{O}$} & 4 & 40 & + \\
\hline & & 10 & 50 & + \\
\hline & & 50 & 60 & + \\
\hline Control & & & 20 & - \\
\hline
\end{tabular}

Fig. 9. Ultraviolet absorption spectrum of 6-Dehydroprogesterone.

O.D.

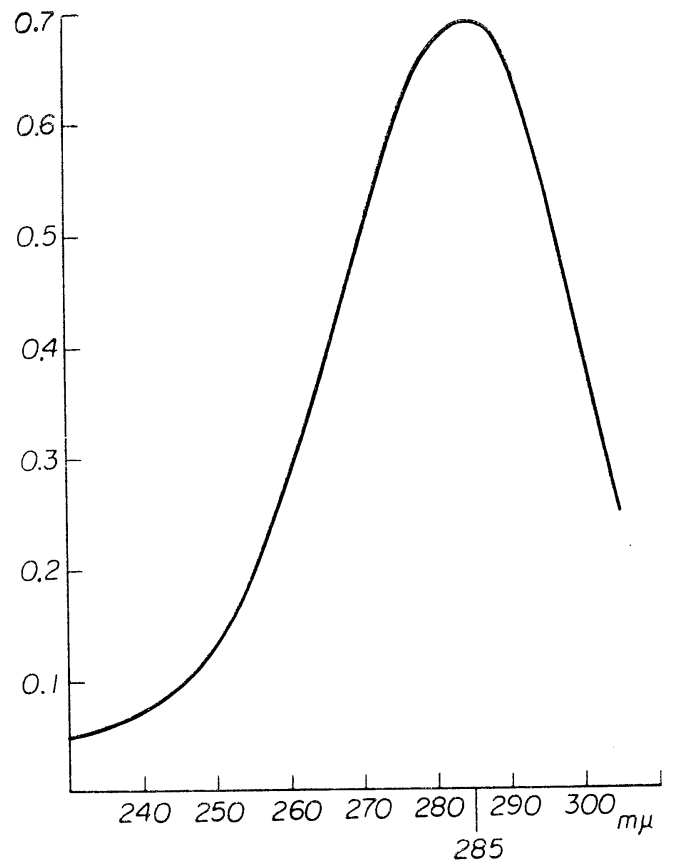

Table6. Bioassay of progestins 実際 6-dehydroprogesterone を投与された家鬼尿中 metabolite は A-ring が還元されていないという結果 を得ている ${ }^{19}$. 


\section{第9章 総括ならびに考按}

Progesterone は生体内で $\Delta^{4}$-3ketone と C-20 ketone の還元体に代謝されると考えられ， pregnanediol が progesterone の代謝産物であるととが Venning \& Browne(193720)，193821))により報告されている。にし てての pregnanediol に至る代謝過程には pregnane3, 30-dione および allopregnane-3, 20-dione が飽和 diol への中間代謝産物であると考えられている。すな わちこれらのものを生体に投与すると，尿中に $5 \alpha$ お よび $5 \beta$ 型の diol が排泄される。また Zander 等22) （1958）は人間の胎盤，黄体抢よび破裂前の卵胞中 にさらに 2 種の中間代謝物のあることを報告した。 すなわち $\Delta^{4}$-pregnen-20 $\alpha$-ol-3-one およびその 20 epimer である。そその化学的構造より両異性体は progesterone の直接の代謝産物であると考えられ， Hooker-Forbes 法抢よび Clauberg 法により progestational activity をもつ progestin とみなされた. そこでとの progesterone の代謝過程を図に示すと Fig.10のようになる.

生体内における progesterone に関する研究は比較的古くから実験され報告されている。緒言でも述べた ように Engel ${ }^{11)}(1941) は$ progesterone を皮下および門脈静脈に注射した家鬼の Clauberg 反応では, 後者 の場合か溺く，脾内に注射してもその活性か溺下するてとから progesterone は主として肝において不活性 化されるものであると報告した. Masson \& $\operatorname{Hoffman}^{23}$ (1945) も家鬼で子宮粘膜の変化を起てすのに経口投与. では皮下注射用量の400倍以上の progesterone を必要とするが，肝切除をしておけば，肝切除をしなかつた ものの50倍以上も progesterone の用量を減ずることができたと報告している。また Riegel 等 $\left.{ }^{24}\right)(1950)$ に よるとマウスおよびラットに ${ }^{14} \mathrm{C}$-progesterone を投与した実験で，その放射性物質は肝において最大とな り，胆汁にはこばれ腸管に出て賚便中に現われる。また胆道の通過障害では尿中に大量に現われることから 胆汁排泄の存在が明らかにされた。 その他 in vivo における progesterone の肝における不活性化に関する 実験は多く25), progesterone の不活性化ならびに構造上の変化か肝で行なわれるととは確実である.

しかし一方 in vitroにおける実験報告は比較的少ないが，石㙇 ${ }^{26}$ (1957)は progesterone と肝 homogenate との incubation 実験および肝の灌流実験において pregnane-3 $\alpha$-ol-20-one, pregnane-3 $\alpha, 20 \alpha$-diol を単離し, Dorfman 等の述べている progesterone $\longrightarrow$ pregnanedione $\longrightarrow$ pregnanolone $\longrightarrow$ pregnanediol $の$ 代謝過 程を認めている。 また Bryson \& Sweat ${ }^{27}$ )(1963)は progesterone-4-G $\mathrm{C}^{14}$ を人の分泌期子宮粘膜と incubate $し \tau 20 \alpha$-hydroxypregn-4-en-3-one, pregnanedione, allopregnanedione, 6 $\beta$-hydroxyprogesterone, pregnane-20 $\alpha$-ol-3-one, unidentified dihydroxy compound の6つの代謝産物を得たと報告している. そして Taylor $\left.^{28}\right)(1955)$ は家鬼肝との incubation 実験で, progesterone は $3 \alpha$-hydroxy-5 $\beta$-pregnan-20-one および 3 $\beta$-hydroxy-5 $\alpha$-pregnan-20-one に転換されたと報告している.

これら progesterone の pregnanediol にいたる代謝のうち肝における最初の metabolic reaction は, A-ring の還元であると考えられて来た. われわれの教室でも tritium labelled progesterone 家兔肝 slice と incubate して得られた metabolite の主なものが. pregnanediol であるととを認めている. 一方 6-dehydroprogesterone はこれを家鬼に投与した場合，尿中に2つの大きな metabolite がみられるがてれ はどれも $\Delta^{4.6}$-diene-3-one steroid であつた。 てれは $\Delta^{6} の 2$ 重結合の導入が A-ring の還元性を低下させ 
たと考えられるが，との steroid は経皮投与で明らかな progestational effect を示したにかかわらず，経口投与したときその效果は 認められなかつた。 てのととから考えると, progesteroneの経口投 与による不活性化も必ずしも A-ring の還元だけでは説明できな い. そこでてのような progesterone の不活性化の原因を経口およ び経皮投与について先ず吸収排泄の面で比較検討してみると, 実験 成績で示したように，経口投与で排洲速度が速く子宮粘膜において 作用する時間が短いととがわかつたので，1日4回分割経口投与す るととにより作用時間が長くなることを期待したが，予想に反して その効果はなく，単なる progesterone の吸収排泄の面からのみで

Table 7. Calculated conversion rate of progesterone to $20 \alpha$-hydroxypregn-4-en3-one (in vivo)

\begin{tabular}{l|c|c|c}
\hline Experiment No. & 1 & 2 & 3 \\
$\begin{array}{l}\text { Method } \\
\text { of administration }\end{array}$ & & & \\
\hline \hline Subcutaneous & 26 & 37 & 33 \\
Oral & 33 & 37 & 48 \\
\hline
\end{tabular}

は両投与方法による效力差を説明できなかつた。

さて従来より progesterone が人体に投与されると， 主として pregnanediol complex として尿中に排溇 され， $\Delta^{4}$-3-ketone steroid としてはほとんど排泄さ れないことが知られているが，家鬼では $\mathrm{C}_{20}$ reduced product である20 $\alpha$-hydroxypregn-4-en-3-one が一部 尿中に排泄され，特に neutral ketonic metaboliteの 主体となつているととが報告されている ${ }^{29}$. 宁なわち A-ring の還元を受けていない型で尿中に排泄されて いるわけである。そこで家鬼に progesterone を経口 投与してその尿中に排泄された 20-ol 体を测定し, 経 皮投与の場合と比較するととで，経口投与時に特に強 い奋-3-ketone の還元が起こるかどうかをしらべてみ た。本実験では尿中に排泄された metabolite の状態 を glucuronide, sulfate, acidic, 等の各 fraction に ついて両投与方法を比較したが，著明な相異は認めら れず，また 20-ol 体の測定值と Thomas 等の行なつ た progesterone の代謝害験成績とから，家鬼体内で 行なわれた progesterone の 20-ol 体への転換率を算 出してみても Table 7 亿示すようにどの投与方法でも

Fig. 11. Inactivation of progesterone

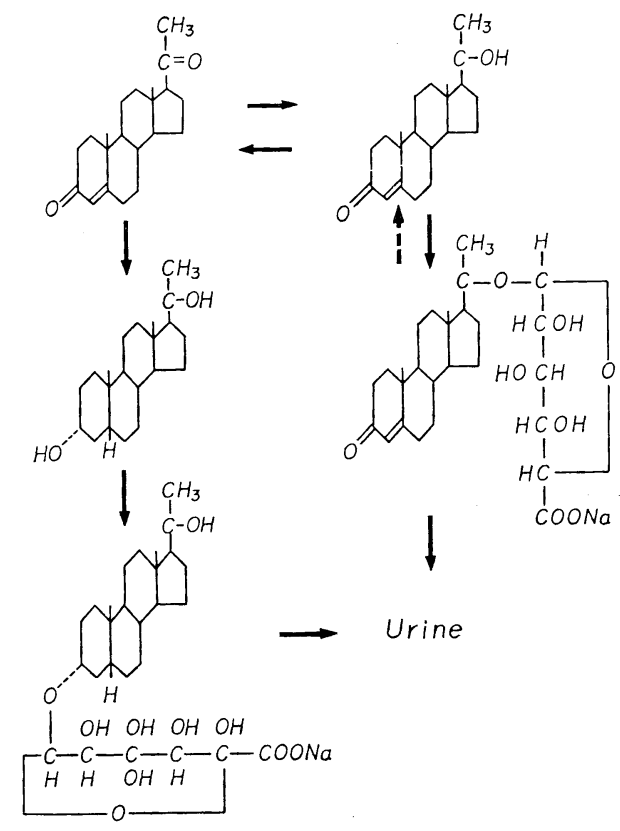

30〜40\%と著明な差がみられなかつた。 とてでての 20-ol 体は経皮投与による Bioassay で progesterone の約 $1 / 2 \sim 1 / 3 の$ 活性を示すととが知られている.したがつて $50 \mathrm{mg} の$ progesterone を経口投与した場合，そ の15mgは体内に 20-ol 体として存在することになり，20-ol 体の存在のみからでも経皮投与 progesterone の 5〜 $7 \mathrm{mg}$ の活性を示さなければならないととになる。しかし事実は $1 \mathrm{mg}$ の経皮投与 progesterone の効 果にも及ばない実験結果を得た。とれはすなわちFig. 11亿示すように progesterone の不活性化は，A-ring の還元による不活性化とさらに progesterone の 20-ol 体の形成に引き続いて起てる glucuronide 形成と いう2つの方法による不活性化を受け，ての glucuronide の deconjugation が起とりにくいと考えるとと によりはじめて説明できるように思われる。乙の仮定を裏付ける急味で ${ }^{14} \mathrm{C}$-progesterone を家兔㳗経経 口両投与をして，そのときの血中 free および glucuronide, sulfate, の各 fraction に対する radioactivity の incorporation をみた，投与後 4 時間目で free fraction が経皮投与で経口投与の約 23 倍の值を示し，経 口投与例では大量の conjugated metabolite が血申゙にられた。

以上いくつかの実験を考え合わせてみると，家我における progesterone の不活性化は，古くから信じら れて来た A-ring の還元のみでなく，20-ketone の還元に引き続いて起てる glucuronide 形成が一つの大 
きな要内を成していることがわかる。このような不活性化機構が，直接人体に当てはまるかどうかについて は，本実験からのみではうかがい得ないが，少なくとも新しく合成された progestin 剤が経口投与でも有効 か否かを決定するのは，本実験て使用したような Clauberg 家鬼に経口投与して定めるものであり，した がつて各種合成 progestin 剤の不活性化の問題を考えるにあたつては，てのような20-ketone の還元に引 き続いて起てる glucuronide 形成をみのがすととができないと考劣られる。

\section{第10章 結語}

Progesterone を経口投与したときの不活性化の原因は, progesterone が肺できのA-ring が漫元される ためであるとされてきた。本実験ではこの不活性化の原因党さらに明らかにする目的で, radioactive progesterone を家鬼に経口投与して経皮投与の場合とその代謝の相異を検討し, 次のような結果を得た.

(1) 㲾中 radioactivity $の$ free, glucuronide, sulfate なよ゙への分布, および metabolite $の$ pattern 亿 は両投与方法に著明な変化がぬられなかつた。

（2）尿中への排泄速度は，経口投与の方が速い傾向がるられたが，経口分制投与での Bioassay の効果は， 経皮投与のを机にはるかに及ばなかつた。

（3）投与された progesterone は，どの投与方法でも約 3〜 4\%が尿中に 20-ol 体として排泄された．

(4) Progesterone 投与後 4 時間目の血中 free steroid は経皮投与例では経口投与例の約 23 倍の值を示し ていた.

(5) 20-ol 体の glucuronide formation が経口投与 progesterone の不活性化の原因として, A-ring の 還元々共に重要な意義があると考えられる。

本論文の要旨は, 徳田教授の第 13 回日本内分泌学会東部部会総会特別講演の一部に発表され, 第13回日本 内分泌学会西日本地方会に招いて発表した。

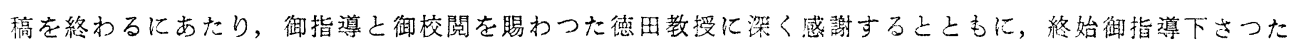
当教室岡田講師をはじめ研究室諸兄に感謝する。

\section{文献}

1) ROSENKRANZ, G. et al : J. Amer. Chem. Soc., $72: 4077,(1950) . \quad$ 2) CORNER, G.W. and W.M. ALLEN : Amer. J. Physiol,, 88 : 340, (1929). $\quad 3$ ) CLAUBERG, C. : Zbl. Gynäk, 54 : 2757, (1930). 4) McPHAIL, M.K.: J. Physiol. (Lond), $83: 145$, (1934). 5) HOOKERFOEBES : Endocrinology, $111: 44,158$ (1947). 6) LUTWAKMANN, C. : J. Endocr., 13 : 26, (1955). 7) PHILPOT, F.J. and J.L. PHILPOT : Biochem. J., $30: 219$ (1936). 8) PINCUS, G. and J. MIYAKE : Endocrinology, $61: 5$, 528, (1957). $\quad 9$ ) MIYAKE, J. and G. PINGUS : Endocrinology, $63: 6,816$ (1958). 10) MARRIAN, G.F. : Biochem. J., $23 ; 1090$, (1929). 11) ENGEL, L.L. : J. Biol. Chem., $137: 205$, (1941). 12) PEALMAN, W.H. et al. : The hormones, New York, $1: 407$, (1948).

13）岩倉哲男：化学の領域, $18: 5,407$, (1963). 14) THOMAS, G.H. : Biochem. J., $83: 450$, (1962). 15$)$ HOFFMAN, M.M. and J.S.L. BROWNE : Fed. Proc., $1: 41$, (1942). 16) FISGHER, R.H. and S.P. McCOLGAN : J. Clin. Endocr., 13:1043, (1953)。 17）平清水大五郎：京都医大誌，70:1，212，（1961）。 18) AGNELle, E.J. and G.D. LAUBACH : J. Amer. Chem. Soc., $79: 1257$, (1957). 岡田弘二他：未発表. 20) VENNING, E.H. and J.B. BROWN : J. Biol. Chem., 119:173, (1937). 21) VENNING, E.H. and J.B. BROWN : J. Biol. Chem., $126: 595$, (1938). 22) ZANDER, J. et al : J. Clin. Endocr., $18: 337$, (1958). 23) MASSON, G. and M.M. HOFFMANN : Endocrinology, $37: 111$, (1945). 24) RIEGEL, B. et al : Endocrinology, 37 : $311,(1950)$. 25) LEBLOND, G.P. : Am. J. Med. Sci.,204 : 566, (1942). 26) ISHI ZUKA, N. : Med. J. Osaka. Univ., $7: 953$, (1957). 27) BRYSON, M.J. and M.L. SWEAT :

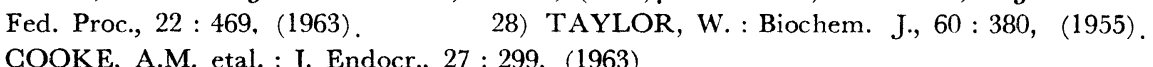
29) COOKE, A.M. etal. : J. Endocr., $27: 299$, (1963). 